\title{
Progesterone-releasing vaginal ring for luteal phase support after superovulation and intrauterine insemination cycles, a pilot study
}

\section{Anel vaginal de progesterona para o suporte lúteo após super-ovulação em ciclos de inseminação intrauterina: estudo piloto}

\author{
Juan-Enrique Schwarze ${ }^{1,2}$, Sonia Villa ${ }^{1}$, Alejandro Manzur ${ }^{3}$, Amiram Magendzo ${ }^{4}$, Ricardo Pommer ${ }^{1,5}$ \\ ${ }^{1}$ Reproductive Medicine Unit at Clinica Monteblanco. \\ 2 Obstetrics and Gynaecology Unit at Universidad de Santiago de Chile. \\ ${ }^{3}$ Reproductive Medicine Unit at Catholic University of Chile. \\ ${ }^{4}$ Reproductive Medicine Unit at Clinica Las Condes. \\ ${ }^{5}$ Institute for Research in Infant and Maternal Medicine, University of Chile.
}

\begin{abstract}
Objective: The main objective of this pilot study was to determine whether a progesterone-releasing vaginal ring is a good alternative for luteal phase support for patients undergoing intrauterine insemination after ovulation induction with sc gonadotrophins.

Material and methods: We performed a multi-center study involving three different reproductive medicine units. Patients included were diagnosed with unexplained infertility and this was their first IUI cycle after ovulation induction with rFSH (Puregon $($ ) ) and ovulation induction with urinary HCG (Pregnyl $\AA$ ). The day of insemination patients were randomized to receive luteal phase supplementation with progestero-

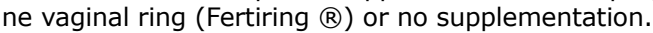

Results: One hundred patients were invited to participate, and completed the study. Forty seven received luteal phase support with Fertiring $\AA$. Overall the pregnancy rate was $15 \%$. It was higher, although without reaching statistical significance, in the group receiving luteal phase support Fertirng ${ }^{\circledR}(19.1 \%)$ than in the group without supplementation $(11.3 \%)$.

Conclusions: In this study, patients undergoing ovulation induction with Puregon $\AA$ and received luteal phase support with Fertiring ${ }^{\circledR}$ showed a higher pregnancy rate than those who received no luteal phase support, although statistical significance was not achieved.
\end{abstract}

\section{RESUMEN}

Objetivo: El objetivo principal de este estudio piloto fue comparar la frecuencia de embarazo por ciclo en pacientes sometidas a inseminación intrauterina después de la inducción de ovulación con o sin apoyo de la fase lútea con Fertiring ${ }^{\circledR}$.

Materiales y Método: Se realizó un estudio multicéntrico, con la participación de tres unidades de medicina reproductiva. Las parejas incluidas tenían el diagnóstico de infertilidad sin causa aparente y era su primer ciclo de inseminación intrauterina tras inducción de la ovulación con FSHr (Puregon (B) e inducción de la ovulación con HCG urinario (Pregnyl®). El día de la inseminación las pacientes fueron randomizadas a recibir suplemento de fase lútea con un anillo vaginal con progesterona (Fertiring $\AA$ ) o a ningún suplemento.

Resultados: Cien pacientes fueron invitadas y completaron el estudio, 47 recibieron soporte de fase lútea con Fertiring $\AA$ y 53 no recibieron. La frecuencia global de embarazo fue de $15 \%$, fue mayor, aunque sin diferencia significativa, en el grupo que recibió soporte de fase lútea con Fertirng ${ }^{\circledR}$ $(19,1 \%)$ que en el grupo que no recibió $(11,3 \%)$.
Conclusiones: En este estudio, las pacientes sometidas a inducción de la ovulación con Puregon $₫$ y que recibieron soporte de fase lútea con Fertiring ${ }^{\circledR}$ mostraron una mayor frecuencia de embarazo que aquellas que no recibieron soporte de fase lútea, aunque ésta no logró significancia estadística.

\section{RESUMO}

Objetivo: Estudo piloto comparando a taxa de gravidez por ciclo em pacientes submetidos a inseminação intra-uterina após a indução da ovulação com ou sem suporte da fase lútea com Fertiring ${ }^{\circledR}$.

Materiais e Métodos: Estudo multicêntrico, com a participação de três centros de medicina reprodutiva . Os casais incluídos foram diagnosticados infertilidade sem causa aparente e foi o seu primeiro ciclo IIU após a indução da ovulação com rFSH ( Puregon ${ }^{\circledR}$ ) e indução da ovulação com HCG urinário ( Pregnyl ${ }^{\circledR}$ ) . No dia da inseminação foram randomizadas para receber suplementação da fase lútea com progesterona anel vaginal ( Fertiring ${ }^{\circledR}$ ) ou nenhuma suplementação.

Resultados: Cem pacientes foram convidadas e completaram o estudo , 47 receberam suporte da fase lútea com Fertiring $®$ e 53 não receberam . Taxa geral de gravidez foi de $15 \%$, mais elevada, embora não significativamente diferente no grupo que recebeu o suporte de fase lútea Fertirng (R) $(19,1 \%)$ do que no grupo sem $(11,3 \%)$.

Conclusões: Neste estudo, os pacientes submetidos a indução da ovulação com Puregon $®$ e suporte da fase lútea com Fertiring $₫$ mostraram uma taxa de gravidez superior do que aqueles que não receberam suporte da fase lútea, embora a significância estatística não tenha sido significativa.

\section{INTRODUCTION}

Unlike assisted reproductive technology cycles such as in vitro fertilisation cycles with own or donated cycles, and the transfer of frozen/thawed embryos, there is no consensus whether luteal phase support is needed in cycles of intrauterine insemination following ovulation induction (Hill et al, 2013) (Cohlen, 2009).

The luteal phase is defined as the period between ovulation and the onset of menses or the establishment of a pregnancy (Kyrou et al, 2010). Normal luteal function requires optimal preovulatory follicular development, luteinization of the granulosa cells to produce progesterone, continued tonic LH support, vascularization of the corpus luteum, and oestrogen to induce progesterone receptors in the endometrium (Kyrou et al, 2010). A normal life-span of the corpus luteum is 14 days unless rescued by human chorionic gonadotrophin. 
Luteal phase support can be administered orally, intramuscularly or vaginally. When the vaginal route is preferred, progesterone can be administered daily as a capsule, as creme or - more recently - can be delivered continuously from a sylastic vaginal ring.

This progesterone-releasing vaginal ring has been successfully used as source of progesterone for luteal phase support in in vitro fertilisation cycles and oocyte donation cycles (Zegers-Hochschild et al, 2000). In the present pilot study, we explore weather the use of this ring increases the clinical pregnancy rate in intrauterine insemination cycles following ovulation induction.

\section{MATERIAL AND METHODS}

The main objective of this pilot study was to compare the clinical pregnancy rate per cycle in patients undergoing intrauterine insemination after ovulation induction with or without luteal phase support with Fertiring $\AA$.

\section{PATIENTS}

Patients consulting in three different reproductive medicine units (Clinica Monteblanco, Clinica Las Condes and the Catholic University) were invited to participate.

Inclusion criteria were: age between 18 and 36 at the time of randomisation; first cycle of intrauterine insemination after ovulation induction; partner with normal semen analysis according to WHO; normal ovarian reserve as determined either by basal FSH levels or antral follicle count, as per centre standard practice; ultrasound identification of both ovaries; normal uterine cavity diagnosed by transvaginal ultrasound and/or histerosalpingography; normal body mass index; bilateral tubal patency identified by histerosalpingography and/or laparoscopy; and willing to give consent to participate in the study.

Exclusion criteria were: leiomyomata requiring surgery; history of $\geq 2$ miscarriages; hypothalamic or hypophyseal tumour; hipersensibility to exogenous gonadotropins; polycistic ovarian syndrome according to Rotterdam consensus; vaginal haemorrhage of unknown aetiology; ovarian tumour; and contraindication to be pregnant.

\section{PROCEDURE}

Patients that fulfilled all inclusion criteria and presented no exclusion criteria were invited to participate. After giving their written consent, the patients were scheduled for a basal ultrasound scan during the first three day of menses. After ruling out any anatomical abnormality, ovulation was induced by daily administration of recombinant FSH (Puregon $®$, Merck-Sharp\&Dohme). Follicular development was followed by periodical ultrasound scans. Once at least one follicle reached $17 \mathrm{~mm}$ diameter, ovulation was induced by the administration of 5,000 IU urinary HCG (Pregnyl ${ }^{\circledR}$, Merck-Sharp\&Dohme), and the number of follicles with $\geq 14 \mathrm{~mm}$ diameter were recorded. Twenty-four to thirty-six hours later, intrauterine insemination was performed, according to each centre's preference.

The day of the insemination each patient was randomised to either luteal phase support with a progesterone-releasing ring (Fertiring ${ }^{\circledR}$, Silesia) or no luteal phase support. Two weeks later a pregnancy test was performed, and when positive, a vaginal ultrasound scan was performed according to each centre's standard practice, and the number of gestational sacs were recorded. Clinical pregnancy was defined as the presence of a gestational sac during ultrasound scan (Nygren et al, 2011).

\section{PROGESTERONE-RELEASING RING}

Fertiring $\AA$ corresponds to a silicone rubber vaginal ring with external diameter of $60 \mathrm{~mm}$ and cross section of 9 $\mathrm{mm}$, manufactured by Laboratorio Silesia, Santiago, Chile. It contains $1 \mathrm{~g}$ of the natural hormone progesterone, homogeneously dispersed. Its in vitro released is in the order of $10 \mathrm{mg}$ of progesterone per day. When placed in the vagi- na it provides a fairly constant release of progesterone for approximately three months.

\section{STATISTICAL ANALYSIS}

Since this is a pilot study, no sample size was calculated, and we decided to invite one hundred patients to participate in the study.

Continuos variables are presented as mean and standard deviation (SD). Numerical variables are presented as mode and minimum and maximum. Relative risk of clinical pregnancy proportion and miscarriage proportion are presented with $95 \%$ confidence interval.

\section{RESULTS}

We did not have any screening failure, thus one hundred patients were invited and completed the study. Forty seven patients received luteal phase support with Fertiring $₫$, and the other fifty three did not. There were no major differences in either the age of the female partner nor in the male partner (table 1).

Table 1. Demographic characteristics

\begin{tabular}{lcc}
\hline & $\begin{array}{c}\text { Luteal phase } \\
\text { support with } \\
\text { Fertiring }\end{array}$ & $\begin{array}{c}\text { No luteal } \\
\text { phase support }\end{array}$ \\
\hline Number & 47 & 53 \\
\hline Age (mean, SD) & $31.5(3.0)$ & $32.3(31)$ \\
\hline Age partner (mean, SD) & $33.5(4.1)$ & $35.0(4.6)$ \\
\hline $\begin{array}{l}\text { Duration of infertility in } \\
\text { months (mean, SD) }\end{array}$ & $46.1(37.2)$ & $57.9(37.2)$ \\
\hline
\end{tabular}

Table 2 shows the main characteristic of the cycles in patients with luteal phase support with Fertiring ${ }^{\circledR}$ and patients without luteal phase support. The number of follicles $\geq 14 \mathrm{~mm}$ and inseminated spermatozoa did not differ significantly between both groups.

Table 2. Cycle outcome

\begin{tabular}{lcc}
\hline & $\begin{array}{c}\text { Luteal phase } \\
\text { support with } \\
\text { Fertiring® }\end{array}$ & $\begin{array}{c}\text { No luteal } \\
\text { phase support }\end{array}$ \\
\hline $\begin{array}{l}\text { Number of stimulation } \\
\text { days (mean, SD) }\end{array}$ & $9.2(1.5)$ & $8.7(1.5)$ \\
\hline $\begin{array}{l}\text { Number of oocytes } \\
\geq 14 \mathrm{~mm}(*) \text { mean } \\
\text { (min-max) }\end{array}$ & $2.0(1.0)$ & $2.0(1.0)$ \\
\hline $\begin{array}{l}\text { Clinical pregnancy } \\
\text { number (\%) }\end{array}$ & $9(19.1)$ & $6(11.3)$ \\
\hline
\end{tabular}

$\left.{ }^{*}\right)$ when ovulation was triggered

Overall, the clinical pregnancy rate per cycle was $15 \%$. It was higher in the group with luteal phase support with Fertiring $®(9 / 47,19.1 \%)$, than in the group without luteal phase support $(6 / 53,11.3 \%)$. However, this difference did not reach statistical significance $(p=0.2739 ; R R 1.7$ with a 95\%CI 0.65-4.40) (table 2).

All sixteen clinical pregnancies were single, and none of them ended in an abortion.

\section{DISCUSSION}

We found that patients undergoing intrauterine insemination after ovulation induction with Puregon $\AA$ and receiving 
luteal phase support with a progesterone-releasing ring, showed a higher pregnancy rate, although without reaching statistical significance. Post hoc analysis revealed that in order that our findings reach statistical significance, 469 patients are needed per study group.

While it has been established that stimulated IVF/ICSI cycles have deficient luteal phases, the question remains whether the quality of the luteal phase when two or three corpora lutea are present only (as is the case in stimulated IUI cycles) is impaired as well.

Our findings are similar to other authors, that induce ovulation with similar protocols than ours, namely using recombinant FSH (Maher, 2011,Agha-Hosseini et al, 2012, Hill et al, 2013). And differ from those inducing ovulation with clomiphene citrate (Kyrou et al, 2010,Erdem et al, 2009). These findings suggest that ovulation induction with gonadotropins induce a relative luteal insufficiency that might be overcome with the administration of exogenous progesterone. There is biological plausibility and clinical evidence to suggest that exogenous gonadotropins and clomiphene citrate may have differing effects on endogenous luteal phase function. The effect of exogenous gonadotropins directly on the ovaries leads to increased serum estradiol and negative feedback on the hypothalamic-pituitary-ovarian axis (Messinis, 2006, Tavaniotou et al, 2002, Tavaniotou et al, 2001), leading to aberrant LH pulsatility and progesterone secretion (Rossmanith et al, 1990). This feedback loop has been proposed as a mechanism of luteal phase dysfunction in gonadotropin-stimulated cycles (Tavaniotou et al, 2002,Tavaniotou et al, 2001, Hill et al, 2013).

None of the pregnant patients experienced a miscarriage. The lack of difference of miscarriage rate between both groups is consistent with other reports. This suggests that the increase in the clinical pregnancy rate is due to an increase of the implantation rate of normal blastocysts, and not due to a disfunction of the endometrium.

Progesterone-releasing vaginal ring is a novel approach to the administration of exogenous progesterone. It has been successfully been used in IVF/ICSI and oocyte donation cycles (Zegers-Hochschild et al, 2000). One of its main advantages is the easy of use, since once it is placed in the vagina, the patient does not need to constantly administered more progesterone, either orally or vaginally, thus reducing the treatment-associated stress. Another advantage is that it concentrates its biological effect in the uterus without elevating the plasma circulatory levels, which are associated with central nervous system side effects such as dizziness and somnolence.

In summary, we found that patients undergoing intrauterine insemination after ovulation induction with progesterone tended to show a better pregnancy rate, when luteal phase support was administered by a progesterone-releasing vaginal ring. Since our study was underpowered to test a superiority hypothesis, more studies are granted to test wether these findings are real or not, and to establish a cost benefit, and to determine the duration of $P$ that is necessary to see clinical benefit.

\section{ACKNOWLEDGEMENTS}

The authors would like to thank Merck-Sharp\&Dohme for providing Puregon and Pregnyl; Laboratorio Silesia for providing Fertiring $\AA^{\circledR}$; and Javier Crosby, PhD for his generous critics of the manuscript.

\section{Corresponding Author}

Camino a Farellones 18780

Lo Barnechea, Santiago, Chile

Tel.: 562-2-31215000

E-mail: jeschwarze@gmail.com

\section{REFERENCES}

Agha-Hosseini M, Rahmani M, Alleyassin A, Safdarian L, Sarvi F. The effect of progesterone supplementation on pregnancy rates in controlled ovarian stimulation and intrauterine insemination cycles: A randomized prospective trial. Eur J Obstet Gynecol Reprod Biol 2012, Dec; 165:249-53.

Cohlen BJ. Should luteal phase support be introduced in ovarian stimulation/IUI programmes? An evidence-based review. Reprod Biomed Online 2009;19 Suppl 4:4239.

Erdem A, Erdem M, Atmaca S, Guler I. Impact of luteal phase support on pregnancy rates in intrauterine insemination cycles: $A$ prospective randomized study. Fertil Steril 2009, Jun;91:2508-13.

Hill MJ, Whitcomb BW, Lewis TD, Wu M, Terry N, Decherney $\mathrm{AH}$, et al. Progesterone luteal support after ovulation induction and intrauterine insemination: A systematic review and metaanalysis. Fertil Steril 2013, Jul 19.

Kyrou D, Fatemi HM, Tournaye H, Devroey P. Luteal phase support in normo-ovulatory women stimulated with clomiphene citrate for intrauterine insemination: Need or habit? Hum Reprod 2010, Oct;25:2501-6.

Maher MA. Luteal phase support may improve pregnancy outcomes during intrauterine insemination cycles. Eur J Obstet Gynecol Reprod Biol 2011, Jul;157:57-62.

Messinis IE. Ovarian feedback, mechanism of action and possible clinical implications. Hum Reprod Update 2006;12:557-71.

Nygren KG, Sullivan E, Zegers-Hochschild F, Mansour R, Ishihara O, Adamson GD, de Mouzon J. International committee for monitoring assisted reproductive technology (ICMART) world report: Assisted reproductive technology 2003. Fertil Steril 2011, Jun;95:2209-22, 2222.e1-17.

Rossmanith WG, Laughlin GA, Mortola JF, Johnson ML, Veldhuis $J D$, Yen SS. Pulsatile cosecretion of estradiol and progesterone by the midluteal phase corpus luteum: Temporal link to luteinizing hormone pulses. J Clin Endocrinol Metab 1990, Apr;70:990-5.

Tavaniotou A, Albano C, Smitz J, Devroey P. Impact of ovarian stimulation on corpus luteum function and embryonic implantation. J Reprod Immunol 2002;55:123-30.

Tavaniotou A, Smitz J, Bourgain C, Devroey P. Ovulation induction disrupts luteal phase function. Ann N Y Acad Sci 2001, Sep;943:55-63.

Zegers-Hochschild F, Balmaceda JP, Fabres C, Alam V, Mackenna $A$, Fernández $E$, et al. Prospective randomized trial to evaluate the efficacy of a vaginal ring releasing progesterone for IVF and oocyte donation. Hum Reprod 2000, Oct;15:2093-7. 